\title{
Psychiatry in Malta
}

\author{
Joseph Roger Saliba
}

Malta, perched between Europe and North Africa, has historically been influenced by a succession of world powers yet has maintained an identity of its own and has long enjoyed an importance far beyond its small size and population.

Malta's medical tradition dates back to the world-famous order of St John's Knights Hospitallers and the Medical School has long-standing links with the United Kingdom. Its medical qualification (MD) has had automatic recognition by the General Medical Council. The island has exported several doctors to the UK, many of whom now hold career posts in various specialities.

Unfortunately, the Maltese medical profession endured 15 years of political conflict under a Labour government during which rifts were created within the medical profession and Malta lost automatic recognition of its MD. Only recently has this been regained and the Medical School has been repairing the damage done. In 1989 the Postgraduate Committee held its First Maltese Medical School Conference which included psychiatric contributions. In 1991 the Medical Association of Malta hosted the 43rd World Medical Assembly where there was a declaration on adolescent suicide.

\section{Psychiatry in Malta}

The history of institutional psychiatry in Malta has been well documented by the Maltese medical historian, P. Cassar (Cassar, 1949) and has been traced back to the 16th century. In 1575 the Holy Infirmary in Valletta had a room especially reserved for insane patients. When they became violent they were removed to the basement wards with windows into the adjacent street. Passers-by looking through these windows could tease and excite patients to the point of fury earning the street the name of 'street of lunatics'.

Malta's present mental institution, Mount Carmel Hospital, was built in 1853. It was to be built "on the most approved modern plans" (Cassar, 1949) yet it was later discovered to be an exact replica of Wakefield Asylum in England which had been built in 1818, and there are serious doubts as to whether the architect was truly an architect.
Malta and its sister island Gozo, with their population of 350,000 , are thus served by this 700-bedded mental institution, a ten-bedded seven-day unit in the general hospital in Malta, and an almost purely custodial 20-bedded hospital in Gozo.

Although Mount Carmel Hospital has undergone a number of improvements it remains essentially an asylum containing mainly chronic. institutionalised patients. Most of the wards are locked, the sexes segregated and with a leave system not unlike the old 'hospital parole', 'ground parole' and 'town parole' system.

\section{Specialist and community services}

Malta finds itself lagging behind Britain and other countries in grappling with the challenges of sub-specialisation and community psychiatry while burdened with the heritage of an outdated asylum and its institutionalised inmates. Although Malta has a ten-bedded high turnover acute unit in the general hospital, this provides minimal remedial therapy beyond rest and psychotropic medication and there is nothing between this short-stay unit and the locked acute admission wards at Mount Carmel Hospital.

On the positive side, the outlook is towards community psychiatry. However, the only significant move in this direction consists of four sectorised, health centre based out-patient clinics with no true community psychiatric nurses due to nurse shortages.

\section{Staffing}

Medical and related staffing levels are far below UK recommended norms and very low even if one accepts more recent trends away from norms towards informed estimation of provision (Hirsch, 1988). Staffing operates on a traditional firm system made up of consultant, senior registrar, senior house officer, house officer and multidisciplinary team comprising clinical psychologist, social worker, occupational therapist and nursing staff. In reality, senior registrars and adequately trained senior house officers are in short supply because several are training abroad so that the department has to utilise inexperienced house officers. There is also a 


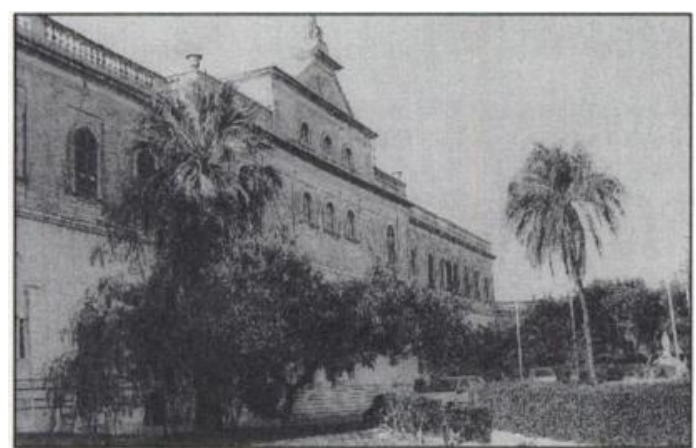

Malta's present mental institution, Mount Carmel Hospital, built in 1853.

severe shortage of properly trained nurses, occupational therapists and clinical psychologists.

\section{Training}

Medical undergraduate psychiatric training is of a high standard and high quality graduates are attracted into psychiatry. There is a regular clinical case conference and journal club training programme, and rotation of trainees. Malta has one year's recognition of training towards MRCPsych but trainees still have to do most of their training in the UK. Also staff trained locally and sent abroad for further training often do not return and this has only partly been mitigated by changes in British immigration laws. The impact on a small island is significant.

In-service and postgraduate training needs to be developed so that a greater proportion of training can take place locally and trained psychiatrists overseas encouraged to return. While Membership of the College and higher training overseas have obvious merits the price paid is losing our in-training manpower for up to eight years. A planned local training programme meeting European community (European Union of Medical Specialists, 1993) and College (Royal College of Psychiatrists, 1993) criteria would allow shorter training periods abroad and anticipate Malta's planned entry into the EC.

\section{Mental health legislation}

Malta's belated 1976 Mental Health Act is closely based on Britain's 1959 Act but actually came into force in September 1981 precisely two years before Britain's 1983 Act became law and does not incorporate any of the amendments. This alone should give some indication of the need for an amended Act.

\section{The way forward}

Notwithstanding Malta's achievement in obtaining part recognition of training clearly much remains to be done. Institutional psychiatry still prevails and progress is hampered by resource limitations and bureaucratic, organisational and local cultural factors.

Important hurdles ahead include formulation of a mental health policy coupled with amendment of the Mental Health Act and implementation of manpower service and training projections. Development of community residential facilities will allow reduction in mental hospital beds. For the British a sense of déjà vu perhaps but not for Malta. And Malta faces this challenge armed with the experience of those it seeks to learn from.

The institutionalising effect of large hospitals is deplorable but the latter's containment of society's less robust members cannot easily be refuted. Recent reappraisals of the history of institutional psychiatry have challenged the attack by revisionist social historians and antipsychiatrists, re-asserting that mental institutions did indeed save these patients from their previously worse plight (Berrios \& Freeman, 1991).

The consequences of rapidly closing down mental hospitals without adequate community provision, as in Italy, are known. In Trieste where the system of psycho-social centres has worked well, their mental hospital San Giovanni is still not closed. Even where the community movement has been more gradual, as in the UK, this has not been an unqualified success and mental hospital funds have not always followed patients into the community.

In measuring the success of community psychiatry, it is fair to consider not merely the freedom of these patients but also their plight. A significant number of vagrants have psychiatric problems and there are indications that the closing down of mental hospitals may merely transfer patients from "the back ward to the back alley" (Klerman, 1977). In Malta one does not see many vagrants.

Although Malta lags behind, the seeds of progress have been sown. Mental health staff are being attracted into the field through university training initiatives. Psychiatrists trained in the UK will be returning which will upgrade Malta's training potential and, by increasing manpower, release others to train in the UK. Malta's health service is scheduled for major reorganisation with substantial financial investment. The government has recently identified mental health reform as a priority and has signed an agreement for help from Leuven University in Belgium. A mental health masterplan is being drawn up and, as part of a major redevelopment 
programme, all acute psychiatric services will start to be moved out of Mount Carmel Psychiatric Hospital into general hospital based acute and specialist units and into the community. A smaller Mount Carmel Hospital will be upgraded to meet the needs of those who will still need longer term hospitalisation.

The whole health management structure in Malta is being reorganised and senior managers are being trained by Birmingham University to achieve greater efficiency and top quality management.

\section{References}

BERRIOS, G.E. \& FREEMAN, H. (1991) Introduction. In 150 Years of British Psychiatry. London: Gaskell (Royal College of Psychiatrists).
CASSAR, P. (1949) The Insttutional Treatment of the Mentally Insane in Malta. Malta Government Printing Office.

EUROPEAN UNION OF MEDICAL SPECIALISTS UEMS HARMONIZATION COMMrTteE (1992) Compendium of Medical Spectalist Training in the EC.

HIRSCH. S.R. (1988) Psychlatric Beds and Resources: factors influencing bed use and service planning. London: Gaskell (Royal College of Psychiatrists).

KLERMAN, G. (1977) Better, but not well: social and ethical issues in the deinstitutionalization of the mentally 111 . Schizophrenia Review. 3, 617.

Royal College of PSYchiATRISTs (1993) Statement on Approval of Training Schemes for General Professtonal Training for the MRCPsych.

Joseph Roger Saliba, Director of Psychiatry, Mount Carmel Hospttal, Attard, Malta

\section{Management Training for Psychiatrists}

\section{Edited by \\ Dinesh Bhugra \& Alistair Burns}

More and more, doctors are required to involve themselves in the management of their services. Part I of this clear and practical book describes the management structures and needs which will be encountered by clinicians, while Part II outlines practical management techniques, including how to deal with personnel, how to negotiate, and how to manage time and stress. Drawing on a wealth of personal experience, the authors emphasise how to get the best for and from services. 260pp., ISBN 0902241435

$£ 15.00$

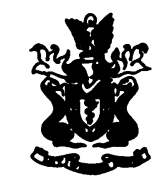

GASKELL 